Currículo sem Fronteiras, v. 20, n. 2, p. 603-613, maio/ago. 2020

\title{
PAST, PRESENT AND CURRICULUM CHALLENGES IN JAPAN: an interview with Kanae Nishioka, Ph.D.
}

\author{
Jaciara de Sá Carvalho \\ Universidade Estácio de Sá - PPGE
}

\begin{abstract}
This paper presents an interview with Dr. Kanae Nishioka, Graduate School professor of Education (Kyoto University) and one of the directors of the National Association for the Study of Educational Methods from the Japanese Society for Curriculum Studies. In this dialogue, Nishioka briefly retrieves the history of curriculum in Japan and explains its organization, discusses curricular centralization, and teacher's autonomy. She demystifies the idea that Japanese schools are heavily equipped with digital technology and that teachers employ them in the classroom. Finally, she presents some challenges to be faced, such as the growth of poverty and the aging of teachers. The interview was conducted in July 2019 and some answers were included by email one year later when the transcript was approved by the interviewee. During these last reviews, some information about actions and concerns related to the COVID-19 pandemic was also included.
\end{abstract}

Keywords: curriculum, education, Japan, COVID-19

\section{Resumo}

Este texto apresenta uma entrevista com a Dra Kanae Nishioka, professora da Faculdade de Educação da Kyoto University e um dos diretores da "National Association for the Study of Educational Methods" da "Japanese Society for Curriculum Studies". Neste diálogo, Nishioka recupera brevemente a história do currículo no Japão e explica sua organização, discute centralização curricular e autonomia dos professores. Ela desmistifica a ideia de que as escolas japonesas estão fortemente equipadas com tecnologias digitais e que seus professores usam esses dispositivos em aulas. Ao final, Nishioka apresenta alguns desafios a serem enfrentados, como o crescimento da pobreza e o envelhecimento dos professores. A entrevista foi realizada em julho de 2019 e algumas respostas complementadas por e-mail um ano depois, quando a transcrição foi aprovada pela entrevistada. Na época, também foram incluídas informações sobre ações e preocupações referentes à pandemia provocada pelo COVID-19.

Palavras-chave: currículo, educação, Japão, COVID-19 


\section{Introdution}

Recently, Brazil has been suffering important curricular modifications in its Basic Education. The high school reform carried out (Brazil, 2017) by the Ministry of Education of the Temer administration promoted radical modifications into the National Education Guidelines and Framework Law - LDB (Brazil, 1996) relative to this level. The following year, under the same government, the National Common Curricular Base - BNCC (Brazil, 2018) was approved. Despite the Base being provided in the LDB, the purpose for the approval has been harshly criticized by researchers specializing in curriculum and entities such as the National Association of Post-Graduate Studies and Research in Education ANPEd and the Brazilian Curriculum Association - ABdC (ANPEd; ABdC, 2018; ANPEd, 2020). According to Macedo (2019, p. 45), "although there has always been some level of curricular centralization in Brazil, it never came to the definition of what should be taught in each subject throughout the different years of schooling across the national territory".

The new guidelines have provoked strong discussion and studies by researchers and teachers throughout the country. Schoolteachers have been appropriating the new guidelines and reframing them, despite their capability to ignore them to a certain degree. The Base implementation movement appears to be slow-going and not a priority of the current Bolsonaro government.

Like in Brazil, other countries face conflicts in implementing their educational guidelines. One such question would be the centrality of "curriculum" versus the freedom of the schoolteachers to develop their concepts of education and practices that meet the specific needs of their students and the local context.

Knowing the reality of other countries helps to reflect on the context and challenges facing education in Brazil. To this end, we interviewed Japan's curriculum specialist, Kanae Nishioka, PhD, during a visit to Kyoto University. This is the second most prestigious university in Japan, behind only the traditional Tokyo University, but ranks first in terms of experimentation and creativity.

Kanae Nishioka is a professor at the Graduate School of Education, Kyoto University. She received her Ph.D. (Education) from the University of Birmingham, UK. Her specialty is the study of curriculum, instruction, assessment, and evaluation. Her main research question addresses how to develop a curriculum that ensures excellent academic achievement for all children. Dr Nishioka's recent research has focused on the implementation of performance assessment. She has conducted several collaborative research and development projects with teachers and schools; consequently, she has published many books, papers, and articles reporting these results. She supervises undergraduate, masters, and doctoral students, and is involved in pre-service teacher training courses at Kyoto University.

She is currently one of the directors of the National Association for the Study of Educational Methods, the Japanese Society for Curriculum Studies, and the Japanese Society for the Study of Educational Objectives and Evaluation. She is currently working for the MEXT as a member of the Expert Committee on the Future Direction of Support Projects for Super Science High School (SSH); she was also a member of an evaluation and promotion 
committee that analyzed research studies on evaluative methods for diverse learning outcomes within senior high schools.

Among her publications is "Curriculum, Instruction and Assessment in Japan" (2016), co-authored with Koji Tanaka and Terumasa Ishii, and published by the publisher Routledge. The book offers an overview of the history and current policy, research and practices of curriculum, classroom instruction and assessment in Japan. The first pages provide the basic framework of Japanese school system, for example, and part of them it's reproduced here for context information (2016, p. 11-12) ${ }^{1}$ :

Japanese schools employ a 6-3-3 system. This means that it comprises six years of elementary school (age 6 to 12), three years of middle-schools (age 12 to 15) and three years of high school. Although elementary and middle school are part of compulsory education, the percentage of students advancing to high school has reached 98\%. [...] School can be divided into state-run, public and private schools. State-run schools are affiliated with national universities. The majority of schools are public schools established by the prefecture or municipality. However, there are quite a number of private schools in urban areas in particular. The middle schools in Japan consist of 73 national schools, 9,707 public schools and 777 private schools (MEXT, 2014).

In the following interview, Nishioka briefly retrieves the history of curricula in Japan and explains its organization, discusses curricular centralization, and teacher's autonomy. She demystifies the idea that Japanese schools are heavily equipped with digital technology and that teachers employ them in the classroom. Finally, she presents some challenges to be faced, such as the growth of poverty and the aging of teachers. The interview was made in July 2019 and some answers were included by email one year later when the transcription was approved by the interviewee. During these last reviews, some information about actions and concerns related to the COVID-19 pandemic was also included.

\section{Interview}

1) I think that the first question should be: With what concept of curriculum do you work, and what authors do you use as reference? Second, what is the meaning of curriculum in this interview considering that you are going to talk about public policies in Japan.

Educational policies in Japan have been strongly influenced by the United States of America. In pre-war Japan the terminology used to refer to a "curriculum" was kyoka-katei (lit. "subjects-program"). In contrast, in the post-war era, we witnessed the introduction of the view that activities commonly considered extracurricular ought to be incorporated into the curriculum. Alongside this change, we see a shift in terminology, with "curriculum" now translated as kyoiku-katei (lit. "educational program"). In other words, the curriculum came to mean a plan for education. Later, in the 1980s, the concept of "hidden curriculum" 
attracted attention. Then, in 1998, we introduced the Period for Integrated Study, as part of the Revised National Courses of Study for that year. This fostered an understanding of the curriculum as a history of a person's learning.

Japanese researchers have looked into a number of theorists from different countries. Works by educators such as John Dewey, Ralph Tyler, Jerome Bruner, Benjamin Bloom, Michael Apple, Ivan Illich, and, of course, Paulo Freire are available in translated versions.

As for myself, I view the curriculum as meaning both the planning and the practice of learning. I have translated Grant Wiggins and Jay McTighe's Book, Understanding by Design (2nd Ed., ASCD, 2005) into Japanese. In the book, they define curriculum as "the specific blueprint for learning for learning that is derived from desired results - that is content and performance standards...." My definition of curriculum is influenced by their ideas.

In fact, we can say that what is important is that we understand the curriculum as comprising three dimensions: (1) an "educational program" intentionally designed by a school; (2) what is actually put into practice by teachers; (3) the learning that is actually achieved by the children. Ultimately, our assessment and evaluation of (3) is what should indicate the work needed to improve (1) and (2).

2) Could you tell us about the curricular organization in Japan? For example, which documents guide the teaching and learning, and what are their characteristics and purposes?

First, the Basic Act on Education sets out the aims and principles of education, while the School Education Law establishes the nation's general educational goals. There is also the Ordinance for Enforcement of the School Education Law, which determines which subjects can be taught in school and how many classroom hours should be assigned to subjects.

The Ministry of Education, Culture, Sports, Science and Technology (MEXT) also issues a public document named the National Courses of Study (NCS). This document lays out the equivalent of what is referred to in other countries as a national curriculum. The NCS are legally binding and are utilized throughout schools in Japan as a standard for developing their curriculum and for MEXT's screening of school textbooks. Along with a basic approach and points to attend to with respect to curriculum development, the NCS also specify educational goals and content for the different school grades and subjects.

As for how the process actually unfolds on the ground at individual schools, the NCS are not the only point of reference for the development of annual teaching plans or unit plans. Teachers also refer to textbooks, reference materials, and similar documents that are composed by textbook companies, boards of education, and so forth.

3) If I understand correctly from the book that you organized with your colleagues, there was a time in Japan where teachers had great autonomy in schools, but the curriculum in Japan is now more centralized. Is the NCS very tight in their restrictions for teachers? What autonomy do the teachers have? 
It really depends on how you see it. After World War II, the United States ruled Japan until 1952 and brought a new system of education to the country. The first NCS was created in 1947 and later revised in 1951. However, these NCSs were only a "draft plan," and were not legally binding. At the time, individual schools were encouraged to freely develop their own curriculum ("educational program"). Then, with the beginning of the Korean War in 1950 and the commencement of the Cold War era, the United States' policy toward Japan also changed. In 1955, the NCS for teaching social studies were revised, with a new emphasis placed on patriotism. In 1958, this Revised NCS was formally announced. The Japanese government tightened control over the curriculum until the 1980s. Then from 1980s until recently, the government decided to adopt Neo-Liberalism policies. In the Revised NCS for 1989, we see attendant praise for emphasizing the individuality of students. Later, the Revised NCS for 1998 pushed for each school to be innovative in pursuing its own unique approach to education. However, once we reach 2007 and the implementation of the National Assessment of Academic Ability (which is a survey of the state of learning in Japan), we actually see a strengthening of the mechanisms whereby the national government inspects educational outcomes. So that is our political landscape.

Having said that, I think that our teachers are quite capable of developing their own lesson plans. They need to use textbooks based on the NCS, but are very keen on developing their own lessons. They may think of what kinds of materials they will use to teach their students or what kinds of questions they will raise in their lessons. They will sometimes organize research groups where they can discuss and get better ideas.

\section{4) Tell us more about these groups. How do they work? Do these groups have university researchers present or is it between teachers only? Do the teachers have an incentive eg. financial support or professional recognition? Also, in your opinion, do these movements involve only a few groups or many of them?}

There are several teacher training opportunities in Japan. Participating in teacher training is part of a teacher's duties in the country. However, there are also teachers who voluntarily attend training sessions and workshops outside of their hours of employment. At these kinds of training sessions and workshops, they are able to learn new approaches and exchange ideas and experiences.

Some teacher training programs are run by the National Institute for School Teachers and Staff Development at the national level, while others are provided by boards of education or universities. I believe there is some form of school-based training taking place at most schools. If a school is particularly passionate, the teachers might undertake some collaborative research, and also hold events where they present their ideas, show their lessons based on these ideas, and engage in discussion with teachers from other schools. There are also cases where schools can be designated as pilot schools by MEXT or boards of education, and receive some extra funding. Sometimes, university researchers are also invited to schoolbased training or to the training run by boards of education, to act as advisors. 
There are also nongovernmental education research groups that have been formed by teachers who participate autonomously in workshops. These kinds of groups can engage in dialogue with other teachers and university researchers, and also publish their own journals. However, with teachers becoming increasingly busy in recent years, the number of participants in such nongovernmental groups is decreasing.

5) Until 2018, the teachers in Brazil only had guidelines (LDB). The teachers had more freedom to apply what worked for their setting. Brazil is very big, and teaching in Sao Paulo is not the same as teaching in one of the smaller towns in the north. Now, we have National Common Curricular Base (BNCC). Some researchers have criticized the BNCC because it does not respect the cultural differences, in addition to other issues.

We face the same challenges. Nowadays, we have bigger economical differences in our society. A large portion of children suffer from poverty. Currently, child welfare problem is one of the greatest problems in Japan, especially because of Neo-Liberalist economic policies. For example, some single parents might be suffering severe poverty and there are some NPO programs that aim to ensure that children are properly nourished. In Japan, some areas are having more poverty problems than others. In well-off areas, children are able to attend piano or swimming lessons after school or attend a juku (a kind of cram school, run by private companies). On the other hand, children from poor areas often find the house empty when they return from school, because their parents are busy with work. Some high school students might need to have a part-time job in order to help out with living expenses. Schoolteachers working in those impoverished areas struggle considerably.

6) That's why I wanted to know more about the autonomy. Do the teachers need to teach exactly same material and give the same tests to everybody?

All schools need to have the textbooks that are approved by the government. There are only a few publishers, and the content of the textbooks are very similar. Here are two middle school math textbooks from different publishers. As you can see, they are the same size and present the same kind of writing and very similar content. This one starts with temperature, the other with height, but the first unit for both is about "positive value and negative value." However, when actual schoolteachers write a lesson plan, even if, for example, they are using a textbook that deals with temperature by introducing the unit, they may make the decision to address height instead.

In the case of tests, the National Assessment of Academic Ability is run by the national government; thus, the tests are held in the same manner across the country. There are cases where boards of education conduct their own scholastic ability tests. However, end-of-unit tests or mid-term/end-of-term examinations held at individual schools may be created by the teachers of the respective schools or produced commercially. Sometimes, schoolteachers 
grade students in ways other than testing, such as with performance tasks or on the basis of their daily observations of students' activities.

\section{7) So the textbook will be the basis for the teaching?}

Yes. Although teachers at a few exceptional schools hardly use textbooks, teachers normally use textbooks when they teach subjects to their students. In the case of public schools, boards of education decide which textbooks are to be used. This means that students learning in the same classroom use the same textbook.

The compulsory education is free for everybody - textbooks included - but you have to pay tuition fees to go to private schools. Some of them are very expensive. I can't afford them.

\section{8) Are private schools more esteemed than public schools?}

From grades one through nine, private schools tend to be recognized better than public ones; however, after tenth grade, which is in high school, some private schools are thought to be better and some worse. High schools are not compulsory and require children to take an entrance exam. Students who fail the entrance exam to public high schools have to attend private schools whose academic standards are lower. In some areas, high schools are quite stratified.

I also note that the percentage of Japanese students who proceed to high school stands at $98.8 \%$, as of a 2018 survey. Meanwhile, the percentage of students who drop out of high school is $1.4 \%$. Although this level of education is not compulsory, the great majority of students attend high school.

9) One hegemonic discourse in Brazil for improving the high schools is to push for the use of digital technology as a means of attracting and keeping the students. The government has developed actions to equip and train teachers for decades, but the integration of technologies and curriculum is one of the main challenges. How does technology play out in Japan's school system?

I believe that the adoption of information and communications technology (ICT) in Japanese schools lags behind other developed nations. Recently, there has been a growing push to have ICT brought into schools at a rapid pace.

First, building on the discussion which took place during the "Classroom of the Future' and EdTech Workshops" (January 2018 - June 2019), the Ministry of Economy, Trade and Industry (METI) has issued invitations for participation in the verification of new systems and has begun to advance a number of projects. Areas of focus include the "STEAM-ificaiton of learning" (Note: Science, Technology, Engineering, Art, and Mathematics), the fostering of "independent / individually optimized learning," and "the creation of a new foundation for learning." 
In December 2019, the cabinet of the Japanese government agreed to a supplementary budget for the purpose of ensuring a ratio of one computer terminal per student, along with access to a high-speed, high-volume communications network. Following this agreement, MEXT is currently pushing forward with its plan for the so-called GIGA school (Note: Global and Innovation Gateway for All). Along with a ratio of one terminal per person and access to high-speed, high-volume networks, the intention is for these schools to make the most of the unique benefits of digital content and learning activities. With such schools, MEXT seeks to establish a model for instruction that places ICT in a more central role when it comes to day-to-day operation.

Because of the impact of COVID-19, many schools were forced to temporarily suspend teaching from March to May, 2020. According to a survey conducted by MEXT in April 2020 , only $5 \%$ of public-school providers (that is, boards of education) conducted "at-home education using simultaneous, bidirectional online instruction." The GIGA school plan was originally intended to be implemented over a five-year time span. However, MEXT has brought forward the schedule with the aim of achieving a ratio of one terminal per student as early as March 2021. Regardless, there are still significant challenges to be overcome if effective classes that make use of ICT are to be made prevalent within Japan. So far, only a limited number of teachers are enthusiastic users of ICT. Typically, teachers run their classes with only a blackboard, notes and worksheets, and at most a projector. Moreover, while school teachers themselves need to learn ICT skills, there is a serious lack of ICT support staff to assist with setting up and utilizing an ICT environment.

With the COVID-19 situation still far from resolved, I believe that the promotion of ICT utilization in schools is a pressing concern. However, I also note that these proposals are not simply about what is best for the education of students. Rather, as we can see from the fact that it was METI which originally pushed for greater ICT use, there are underlying economic considerations at play here. Personally, I am apprehensive that Japan's public education budget may be redirected to ICT-related industries, with a resultant decline in the hiring of teachers. One of the strong points of Japan's schools is that there is a culture of students forming their own collaborative groups, where they are able to learn with and from each other. If we proceed with a more individually optimized approach to learning, then there is a risk that this kind of positive aspect may be lost.

\section{0) What are the main challenges for $\mathrm{K}-12$ schools in Japan in your opinion?}

At the moment, in July 2020, preventing the spread of COVID-19 is a pressing concern. School teachers are working hard not only to ensure the health and safety of their students, undertaking activities such as the disinfecting of learning environments themselves, but also to make up for the learning time that was lost during the period when schools were closed. In dealing with various emergencies in this manner, there is a real concern that teachers are becoming exhausted.

Currently, the implementation of the Revised NCS for 2017-18 is a major issue in Japanese schools. Because there is an initial transition period, the implementation of the new 
NCS is staggered, with elementary school implementation from 2020, middle school implementation from 2021, and high school implementation from 2022.

In the 2003 Program for International Student Assessment (PISA), Japan's reading literacy results were around average in comparison with OECD nations. This was revealed in 2004. As Japanese students usually ranked high in international scholastic ability surveys, this result came as quite a shock (indeed it was referred to as the "PISA shock"). While Japan placed more emphasis on the acquisition of knowledge and skills in the past, with the 2008 Revised NCS, a new emphasis was placed on students developing "the ability to think, to make decisions, to express themselves and other abilities that are necessary to solve problems by using acquired knowledge and skills".

This shift was followed by the influence of discussion surrounding OECD key competencies, as well as international research into $21^{\text {st }}$ century skills. As a result, the 2017 Revised NCS announced a policy of fostering students' competencies through "proactive, interactive, and authentic learning." In other words, to a new extent, emphasis is being placed on the fostering of competencies such as language ability, information literacy, problem discovery and solution ability. At elementary schools, we do see a broad adoption of such proactive and interactive learning. However, as classes at many high schools are still run as lectures, I believe it is in such schools in particular where there will be a greater need for a change in teaching methods.

One thing I am attempting to persuade schoolteachers to do is to change the image of goals for their teaching. I am attempting to let schoolteachers understand that their work is not just to tell students "This is the answer. Please remember it." Rather, I am seeking to train them to have a better idea of goals for education, which are letting students have a deep understanding and enabling them to raise essential questions. This is why I try to get teachers to use the ideas advocated in the book Understanding by Design, as well as to encourage them to develop their own performance tasks. This is my personal challenge.

\section{1) Finally, I would like ask you what is the biggest challenge for education in Japan today?}

The Japanese educational standards have been very high until recently, because, I believe, our teachers' teaching ability has also been high. However, despite the ongoing rapid drop in the number of children in Japan, large class sizes have been maintained. This has meant that the age composition of the country's teachers has become distorted. In many regions, there are a lot of teachers who are in their late 50s, while teachers in their 40s are rare. There are some regions where the hiring of young teachers is increasing alongside the retirement of older teachers as they reach 60 years of age. However younger teachers do not necessarily have a high level of skill, and the knowledge of experienced teachers is not something that can be easily passed on.

Furthermore, the harshness of the teaching work is receiving greater attention from the public. The working hours, for example, are exceedingly long. Teachers must also struggle with the diverse needs of their students while having to respond to the demands of their 
parents and guardians. The number of students who desire to become teachers is decreasing and, depending on the board of education in question, it is becoming difficult to find a sufficient number of students to sit teaching staff examinations for the purpose of ensuring quality. So I feel that Japanese educational standards can rapidly decline if new teachers are not well trained.

There are also problems of child poverty, as I mentioned before. In recent years, it has been said that one in seven children in Japan is living in a state of "relative poverty." To say that someone is in "relative poverty" means that his/her disposable income is less than half of the median of the nation's citizens. Such children tend to be disadvantaged with respect to their access to food, medical care, study, and further education opportunities. As the economic situation is growing worse alongside the COVID-19 pandemic, there is a concern that the problem of child poverty will grow more severe.

In fact, Japan is a nation with extremely limited public expenditure on education. In 2016, the various OECD members announced the percentage of GDP corresponding to their public expenditure on education, from elementary school to university. Japan spent $2.9 \%$, the lowest of the 35 nations to which it could be compared. The average is $4.0 \%$, with Norway the highest at $6.3 \%$. The United States of America expends 4.1\%. Personally, I would like to see an expansion of the budget for education and welfare. However, Japan's national finances are in a difficult state. In recent years there has been a tendency for budgeting to go to projects that meet national policies, rather than for a more uniform distribution of funds. This trend contributes in part to the strengthening of the government's control over schools and universities.

\section{Thank you, professor Nishioka.}

\section{Notes}

1. In 2019, the middle schools in Japan consist of 70 national schools, 9,371 public schools and 781 private schools. Available at: <https://www.mext.go.jp/b_menu/toukei/002/002b/koumoku.html>. Acessed on: 13 August 2020.

\section{References}

National Association of Post-Graduation and Research in Education - ANPEd; Brazilian Curriculum Association - ABdC. (2018). Explanatory Memorandum: BNCC-EM. Avaliable at: http://www.anped.org.br/sites/default/files/images/anped_abdc_contrabncc-emago2018final.pdf. Acessed on: 06 aug. 2018

National Association of Post-Graduation and Research in Education - ANPEd. ANPEd and BNCC: struggle, resistance and denial. (2020). Available at: https://anped.org.br/content/anped-e-bncc-luta-resistencia-enegacao. Acessed on: 16 aug. 2020

Brazil. (1996). Law 9.394/96. National Education Guidelines and Framework Law (LDB). Avaliable at: http://www.planalto.gov.br/ccivil_03/leis/L9394.htm. Acessed on: 28 may 2017.

Brazil. (2017). Law 13.415/17. Available at: 
https://www2.camara.leg.br/legin/fed/lei/2017/lei-13415-16-fevereiro-2017-784336-publicacaooriginal152003-pl.html. Acessed on: 15 jan. 2020

Brazil. National Common Curricular Base. 2018. Available at: http://basenacionalcomum.mec.gov.br/. Acessed on: 15 jan. 2020.

Macedo, Elizabeth Fernandes de. (2019). Making the Core come true: skills and the germ of comparison. Revista Retratos da Escola, Brasília, v. 13, n. 25, p. 39-58. http://dx.doi.org/10.22420/rde.v13i25.967

Tanaka, Koji; Nishioka, Kanae \& Ishii, Terumasa. (2016). Curriculum, Instruction and Assessment: Beyond Lesson Study, Routledge, September 2016, pp.11-27.

\section{Selected Bibliography}

Nishioka, Kanae. (2006). Classroom Management in Postwar Japan: The Life Guidance Approach. In Evertson, C. \& Weinstein, C. (Eds.), Handbook of Classroom Management: Research, Practice, and Contemporary Issues, Lawrence Erlbaum Associates, Mahwah, New Jersey, pp.1215-1237.

Nishioka, Kanae. (2009). Issues Surrounding Academic Achievement in Japan: Examining the 2008 revisions of the National Courses of Study. In Japanese Educational Research Association, Educational Studies in Japan, No.3, pp.5-16.

Nishioka, Kanae. (2011). "Educational Assessment and Lesson Study" in National Association for the Study of Educational Methods (ed.) Lesson Study in Japan, Keisuisha, pp.354-366.

Nishioka, Kanae. (2016). "Historical overview of curriculum organisation: National control over curriculum vs. school-based curriculum development", "Portfolio assessment in the period for integrated study", "Performance assessment in subject teaching", and "Conclusion". In Tanaka, K.; Nishioka, K. \& Ishii, T. Curriculum, Instruction and Assessment: Beyond Lesson Study, Routledge, September 2016, pp.11-27, 112-12, 127-142, and 143-148.

Nishioka, Kanae. (2017). "Hama Omura's Unit learning practice for Japanese classes". In: Yamasaki, Y. \& Hiroyuki, K. Educational progressivism, cultural encounters and reform in Japan, Routledge, June 2017, pp.139-153.

Special thanks to Gregory Collins.

\section{Correspondência}

Jaciara de Sá Carvalho: Universidade Estácio de Sá - PPGE

E-mail: jsacarvalho@gmail.com

Orcid: https://orcid.org/0000-0003-1497-3930

Entrevista publicada em Currículo sem Fronteiras com autorização da autora. 